\title{
Theoretical calving rates from glaciers along ice walls grounded in water of variable depths
}

\author{
T. Hughes \\ Department of Geological Sciences and Institute for Quaternary Studies, University of Maine, Orono, Maine 04469, U.S.A.
}

\begin{abstract}
Calving has been studied for glaciers ranging from slow polar glaciers that calve on dry land, such as on Deception Island $\left(63.0^{\circ} \mathrm{S}, 60.6^{\circ} \mathrm{W}\right)$ in Antarctica, through temperate Alaskan tide-water glaciers, to fast outlet glaciers that float in fiords and calve in deep water, such as Jakobshavns Isbræ $\left(69.2^{\circ} \mathrm{N}, 49.9^{\circ} \mathrm{W}\right)$ in Greenland. Calving from grounded ice walls and floating ice shelves is the main ablation mechanism for the Antarctic and Greenland ice sheets, as it was along marine and lacustrine margins of former Pleistocene ice sheets, and is for tide-water and polar glaciers. Yet, the theory of ice calving is underdeveloped because of inherent dangers in obtaining field data to test and constrain calving models. An attempt is made to develop a calving theory for ice walls grounded in water of variable depth, and to relate slab calving from ice walls to tabular calving from ice shelves. A calving law is derived in which calving rates from ice walls are controled by bending creep behind the ice wall, and depend on wall height $h$, forward bending angle $\theta$, crevasse distance $c$ behind the ice wall and depth $d$ of water in front of the ice wall. Reasonable agreement with calving rates reported by Brown and others (1982) for Alaskan tide-water glaciers is obtained when $c$ depends on wall height, wall height above water and water depth. More data are needed to determine which of these dependencies is correct. A calving ratio $c / h$ is introduced to understand the transition from slab calving to tabular calving as water deepens and the calving glacier becomes afloat.
\end{abstract}

\section{INTRODUCTION}

A largely neglected field of glaciological research is the calving dynamics of glaciers and ice sheets along the fronts of grounded ice walls and floating ice shelves. Yet, calving into the sea is the dominant ablation mechanism of the Antarctic ice sheet and a major ablation mechanism of the Greenland ice sheet. Calving was also a major factor in the retreat of marine (Hughes, 1977; Andersen, 1981; Mayewski and others, 1981) and lacustrine (Andrews, 1973; Hughes, 1987; Teller, 1987; Grosswald, 1988) margins of Northern Hemisphere ice sheets during the last deglaciation. In modeling Antarctic deglaciation, ice-calving rates had to be parameterized in rather arbitrary ways because little was known about calving dynamics, yet calving rates are a critical constraint on retreat rates in the models (Thomas and Bentley, 1978; Stuiver and others, 1981; Fastook, 1984).

Attempts to understand the interaction between glaciation and climatic change cannot afford to ignore calving dynamics (Paterson and Hammer, 1987). Nor can calving dynamics be ignored in modeling simulations of deglaciation and rising sea level in response to "greenhouse" warming over the next few decades, as fossil fuels are consumed. In this context, calving dynamics are particularly important for the fast ice streams that discharge upwards of $90 \%$ of Antarctic and Greenland ice into the sea. Moving $7 \mathrm{~km} \mathrm{a}^{-1}$ along its calving front
(Echelmeyer and Harrison, 1990), Jakobshavns Isbræ $\left(69.2^{\circ} \mathrm{N}, 49.9^{\circ} \mathrm{W}\right)$ is the fastest known ice stream, and its calving rate equals its velocity (Pelto and others, 1989). Rapid calving rates are part of the Jakobshavns effect, a series of positive feed-backs for rapid deglaciation of Jakobshavns Isbræ, in which ice-stream flow produces a heavily crevassed surface, allowing summer surface meltwater thermally to soften deep ice and lubricate the bed, thereby increasing velocity, crevassing, melting and calving, in that order (Hughes, 1986). Since 1964, retreat of the calving front linked to those feed-backs has been halted near the headwall of Jakobshavns Isfjord, but what if "greenhouse" warming produces this "Jakobshavns effect" of fast velocity and calving in all Greenland and Antarctic ice streams with no fiord headwalls (Hughes, 1987). The Jakobshavns effect can be defined as deglaciation of marine ice-sheet margins by rapid calving, so that ice melting is accomplished primarily by floating icebergs to warmer ocean waters, instead of by bringing atmospheric warmth to the ice sheet.

Enough is known about calving dynamics to realize the complexity of this glaciological process. Reeh (1968) made the first theoretical analysis of calving along the floating fronts of glaciers, using calving from Jakobshavns Isbræ, as reported by Carbonnell and Bauer (1968), to test his theory that calving resulted from bending stresses induced by the imbalance of hydrostatic forces in ice and water at the calving front. His results predicted maximum 
tensile bending stresses about one ice thickness behind the calving front, which was compatible with the observation that tabular icebergs were of about these proportions. Fastook and Schmidt (1982) developed a finite-element model that duplicated these results and extended them to include enhanced calving along water-filled crevasses. Scattered crevasses on Jakobshavns Isbræ are filled with water, but none reach the calving front in that condition.

Holdsworth (1969, 1971, 1973, 1974, 1977, 1985) has made detailed theoretical and observational analyses of flexure along the grounding line of floating glaciers, caused by tidal and wave action, as a mechanism for releasing very large tabular icebergs. Other studies of this mechanism were by Robin (1958, 1979), Hughes (1977), Lingle and others (1981), Holdsworth and Glynn (1978, 1981) and Vinogradov and Holdsworth (1985). Hughes (1983) has argued that large tabular icebergs would be released from floating ice shelves along lines of weakness that formed from rifts alongside ice streams that supplied the ice shelf and from gashes through the ice shelf in the lee of ice rises, in addition to flexure along ice-shelf grounding lines, and that these lines of weakness divided an ice shelf into plates that were potential tabular icebergs long before the plates reached the calving front. Wordie Ice Shelf in the Antarctic Peninsula seems to be disintegrating along these lines of weakness at the present time (Doake and Vaughan, 1991).

Iken (1977) made the first theoretical study of slab calving from an ice wall undercut along the shoreline of a beach. She assumed homogeneous deformation based on continuum mechanics to conclude that slabs were about as thick as the height of the ice wall. Hughes (1989) reported non-homogeneous deformation in an ice wall on Deception Island $\left(63.0^{\circ} \mathrm{S}, 60.6^{\circ} \mathrm{W}\right)$, from which slabs having much less thickness calved along shear bands caused by a bending moment at the base of the ice wall.
This mechanism was later observed to be dominant for glaciers entering water in the Chilean Andes and along the Antarctic Peninsula, even when the ice wall was undercut along the water line by wave action (Hughes and Nakagawa, 1989). A theoretical formula derived for this mechanism on Deception Island had a summer calving rate proportional to the inverse square of the icewall height. A summer calving rate inversely proportional to the square of ice height above ice height supported by water buoyancy was reported for the ice wall of Columbia Glacier by Brown and others (1982), who also observed an annual calving rate proportional to water depth for 12 Alaskan tide-water glaciers, including Columbia Glacier. These calving relationships were also discussed by Meier and others (1980), Sikonia (1982) and by Bindschadler and Rasmussen (1983).

Studies of calving dynamics, whether slab calving from ice walls or tabular calving from ice shelves, are a neglected part of glaciology largely because of dangers inherent in calving environments, especially calving into water. The mobility of field workers is severely limited along marine and lacustrine calving ice margins, and calving from ice cliffs up to $100 \mathrm{~m}$ or more above water level is unpredictable and can be frequent. Our detailed studies of calving dynamics on Deception Island were possible only because the calving ice wall was standing on dry land and solifluction of a thick ash layer on the glacier surface had produced a series of ash ramps that gave us safe access to various heights along the ice wall (Brecher and others, 1974; Hughes and others, 1974; Hughes, 1989; Hughes and Nakagawa, 1989).

\section{THEORY}

Direct observations of the calving ice wall on Deception

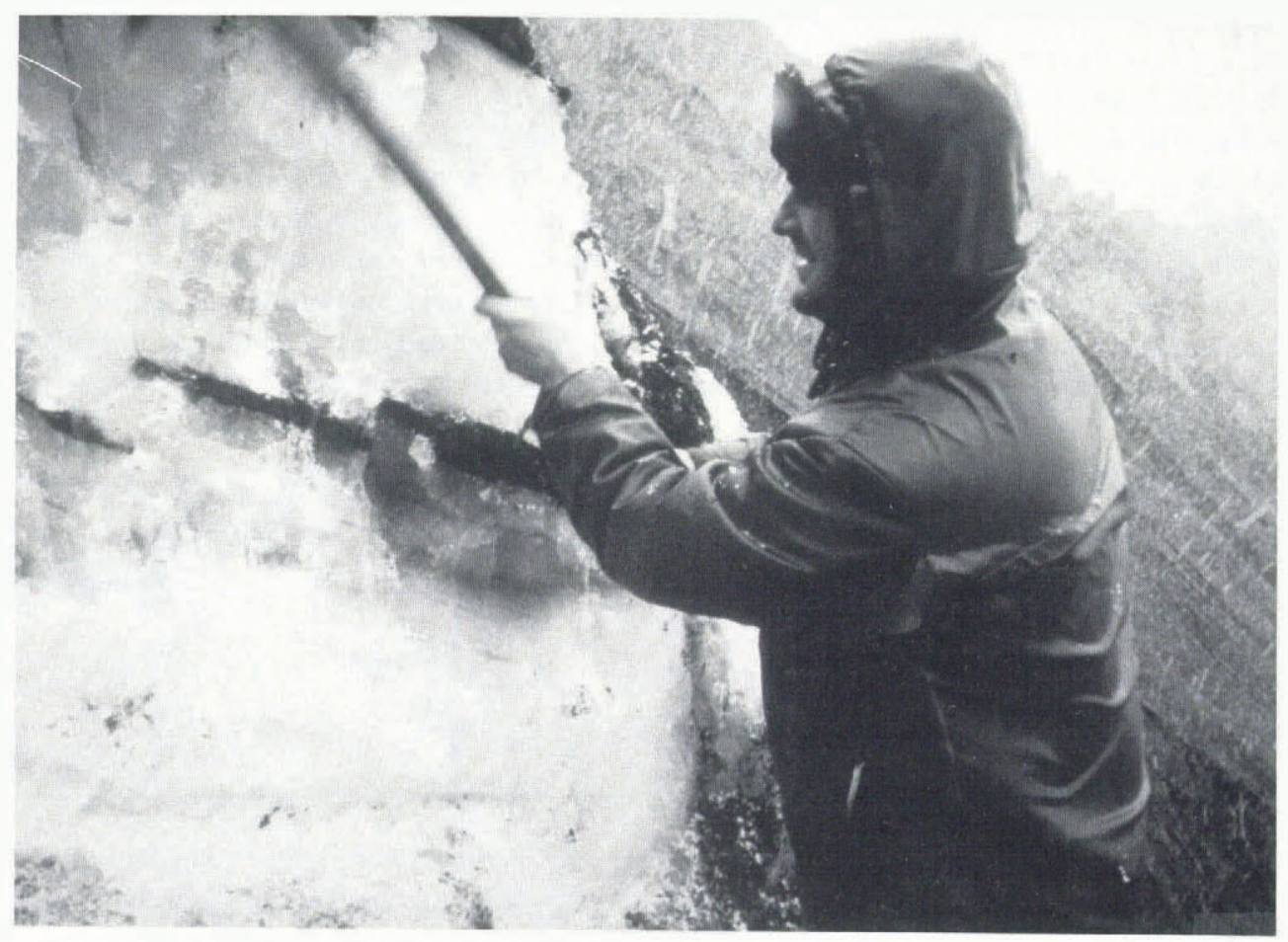

Fig. 1. Shear bands on the Deception Island $\left(63.0^{\circ} \mathrm{S}, 60.6^{\circ} \mathrm{W}\right)$ ice wall revealed by vertical offsets of ash layers in the ice. Access to the ice wall was by ash ramps of various heights, one of which is in the background. 


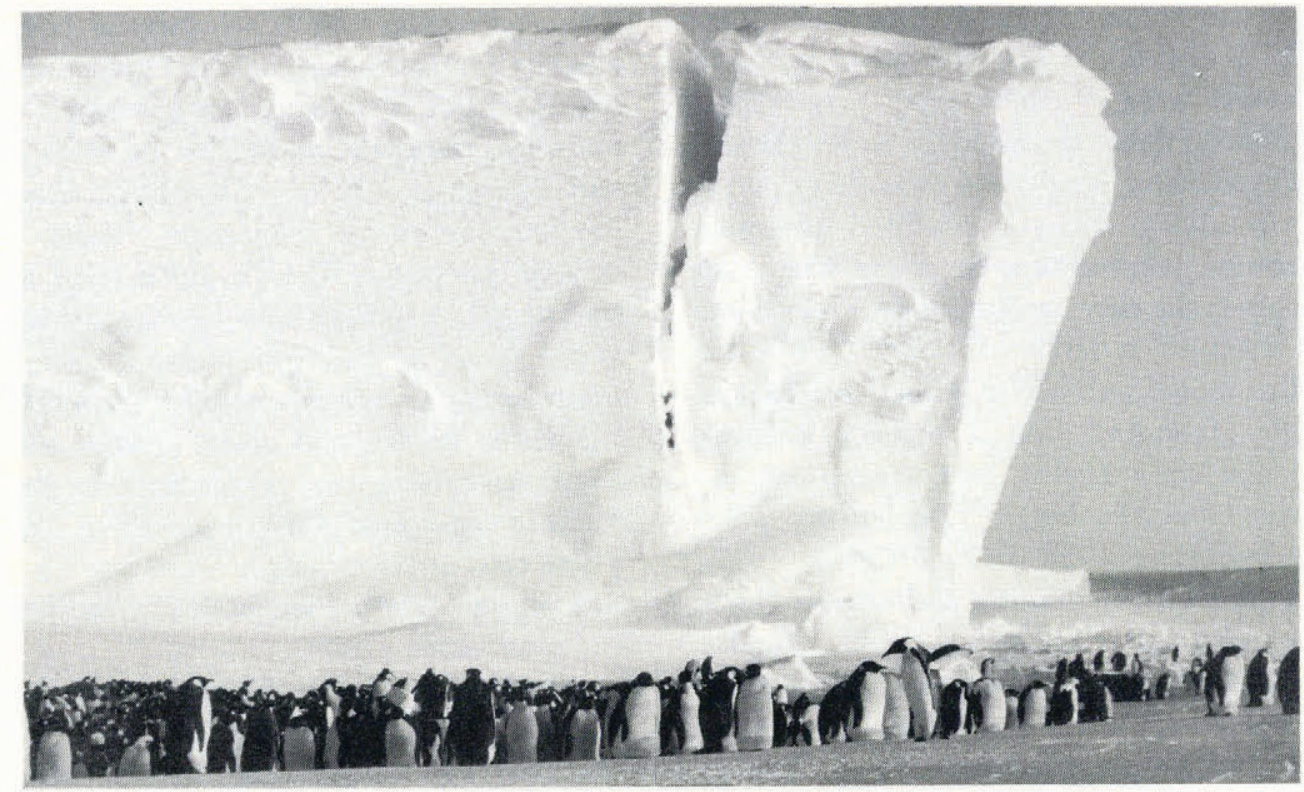

Fig. 2. A slab about to calve from the ice wall of an Antarctic glacier (photograph by D. Allan).

Island, including tunneling into the wall at various heights, revealed numerous shear bands that rose vertically from the bed behind the ice wall and curved increasingly forward with increasing distance above the bed, so that shear displacement increased from zero at the bed to a maximum at the surface (Hughes, 1989). Some of these shear bands are shown in Figure 1. Nonhomogeneous bending creep produces the shear bands, and shear in them is similar to the slip between pages of a book when the book is bent about its binding.

Shear rupture across a shear band leads to the kind of slab calving shown in Figure 2. Shear rupture in a shear band at calving distance $c$ behind the ice wall opens a crevasse that removes coupling of the slab to the glacier. As the crevasse deepens, the entire weight of the slab must be borne by ice at the base of the slab, and by ice below the crevasse tip that still connects the slab to the glacier. If the basal ice is crushed by the ice load above it, the slab will crash vertically downward. If the crevasse widens as it deepens, the slab will continue to bend until it topples forward. Let $\theta$ be the angle of forward bending for the ice slab. The slab will collapse downward when $\theta$ and $c$ are small, because the crushing stress is high, and topple forward when $\theta$ and $c$ are larger, because the bending stress is high. An overhanging ice wall is therefore necessary for forward calving but not for downward calving. In Figure 2, the ice wall looks like it could calve either way. The slab bends forward at $\theta \approx 18^{\circ}$ from the vertical and the crevasse formed at $c \approx 0.4 h$ behind the wall, where $h$ is the wall height. This combination of $\theta$ and $c / h$, therefore, may be close to the transition from downward calving to forward calving. There is no special significance in this transition.

The mechanics of slab calving used here will be based on the theory for bending beams, as presented by Popov (1952) with appropriate modifications. Popov (1952, p. 89) listed the eight steps in beam analysis needed to determine the shear force, the axial force, and the bending moment at any cross-section of a beam. An initially vertical beam of ice resting on the bed will be considered. The beam has length $c$, width $w$ and mean height $\bar{h}$. In general, an ice wall stands in water, so distributed loads of ice and water act on opposite sides of the beam, causing the beam to bend forward. As shown in Figure 3, when water of depth $d$ rises against a wall of height $h$, increasing buoyancy decreases basal shear stress $\tau_{0}$, thereby causing a reduction of surface slope $\alpha$, such that $\tau_{0}$ and $\alpha$ approach 0 when the ice wall begins to float

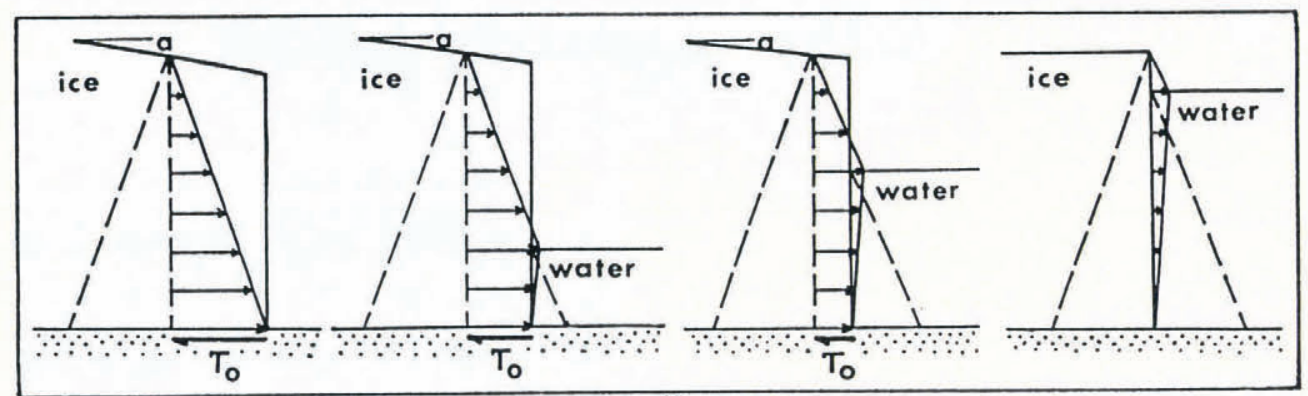

Fig. 3. The effect of water depth on an ice wall. Arrows show the difference between the lithostatic pressure in ice and the hydrostatic pressure in water (sloping dashed lines). This pressure difference, basal shear stress $\tau_{0}$, surface slope $\alpha$, and perhaps slab-size decrease as water deepens, with $\tau_{0}=\alpha=0$ at flotation depth, when tabular calving replaces slab calving. 


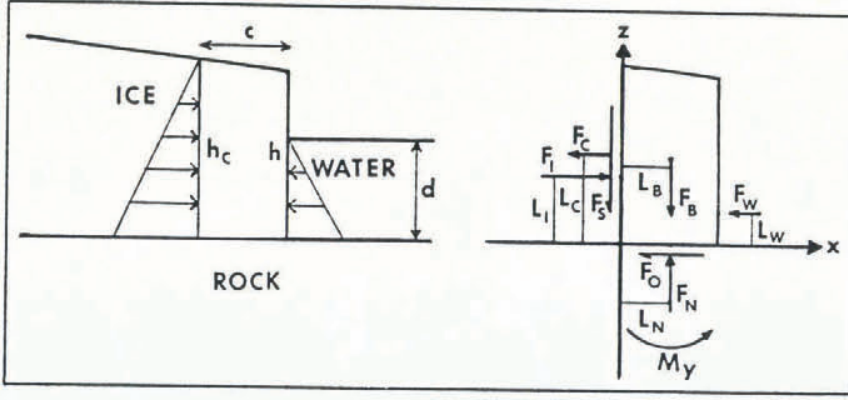

Fig. 4. Free-body diagrams for a slab at an ice wall before shear rupture detaches the slab. Left: boundary conditions; right: forces and moments.

at $d=\left(\rho_{\mathrm{I}} / \rho_{\mathrm{W}}\right) h$, where $\rho_{\mathrm{I}}$ and $\rho_{\mathrm{W}}$ are ice and water densities, respectively, and are assumed to be constant. Questions to be examined are whether $\theta$ and $c$ depend on $d$ and $h$, and how calving rate $u_{\mathrm{c}}$ depends on $\theta, c, d$ and $h$. Specifically, an approximate calving rate that depends on these variables will be derived.

Step 1 consists of producing a free-body diagram in which all forces acting on the beam, taken as the slab that will calve, are referenced with respect to orthogonal coordinates. Figure 4 presents the diagram. The origin of Cartesian coordinates is on the bed at calving distance $c$ behind the ice wall, with $x$ horizontal and positive forward, $y$ horizontal and parallel to the wall, and $z$ vertical and positive upward. Action forces are the distributed horizontal lithostatic force of ice $F_{\mathrm{I}}$ on the left side of the slab, the distributed horizontal hydrostatic force of water $F_{\mathrm{W}}$ on the right side of the slab, and the vertical body force $F_{\mathrm{B}}$ of the slab itself. These are all gravitational forces, with $g$ being gravity acceleration. Good approximations for dynamic equilibrium are:

$$
F_{\mathrm{I}}=\left(\frac{1}{2} \rho_{\mathrm{I}} g h_{\mathrm{c}}\right) w h_{\mathrm{c}}=\frac{1}{2} \rho_{\mathrm{I}} g w h_{\mathrm{c}}^{2}
$$

where $\frac{1}{2} \rho_{\mathrm{I}} g h_{\mathrm{c}}$ is the mean lithostatic pressure pushing on area $w h_{\mathrm{c}}$ for ice thickness $h_{\mathrm{c}}$ at calving distance $c$,

$$
F_{\mathrm{W}}=\left(\frac{1}{2} \rho_{\mathrm{W}} g d\right) w d=\frac{1}{2} \rho_{\mathrm{W}} g w d^{2}
$$

where $\frac{1}{2} \rho_{\mathrm{W}} g d$ is the mean hydrostatic pressure pushing on area $w d$ for ice thickness $h$ at the ice wall and

$$
F_{\mathrm{B}}=w c \bar{h} \rho_{\mathrm{I}} g-w c d \rho_{\mathrm{W}} g=\rho_{\mathrm{I}} g w c \bar{h}\left(1-\rho_{\mathrm{W}} d / \rho_{\mathrm{I}} \bar{h}\right)
$$

where $\bar{h}=\frac{1}{2}\left(h+h_{\mathrm{c}}\right)$ is the average slab height, $w c \bar{h}$ is the slab volume and wcd is the water volume it displaces.

Step 2 consists of adding reaction forces to the freebody diagram. As located in Figure 4, these are a vertical basal normal force $F_{\mathrm{N}}$, a horizontal basal traction force $F_{0}$, a vertical shear force $F_{\mathrm{S}}$ and a horizontal tensile force $F_{\mathrm{C}}$ that opens the crevasse at $c$ :

$$
F_{\mathrm{N}}=\sigma_{z z} w c
$$

where horizontally averaged basal axial stress $\sigma_{z z}$ acts through the substrate normal to basal area $w c$,

$$
F_{0}=\tau_{0} w c
$$

where horizontally averaged basal shear stress $\tau_{0}$ acts parallel to basal area $w c$,

$$
F_{\mathrm{S}}=\tau_{\mathrm{s}} w h_{\mathrm{c}}
$$

where vertically averaged bending shear stress $\tau_{\mathrm{s}}$ induced by $F_{\mathrm{S}}$ acts parallel to calving area $w h_{\mathrm{c}}$, and

$$
F_{\mathrm{C}}=\sigma_{x x} w h_{\mathrm{c}}
$$

where vertically averaged axial stress $\sigma_{x x}$ acts normal to calving area $w h_{\mathrm{c}}$.

Step 3 consists of measuring moment lever arms $L_{\mathrm{I}}, L_{\mathrm{W}}$, $L_{\mathrm{B}}, L_{\mathrm{N}}, L_{\mathrm{O}}, L_{\mathrm{S}}$ and $L_{\mathrm{C}}$ parallel to axes $x, z$ for forces $F_{\mathrm{I}}$, $F_{\mathrm{W}}, F_{\mathrm{B}}, F_{\mathrm{N}}, F_{\mathrm{O}}, F_{\mathrm{S}}$ and $F_{\mathrm{C}}$, respectively, for bending moment $M_{y}$, where:

$$
\begin{aligned}
L_{\mathrm{I}} & =\frac{1}{3} h_{\mathrm{c}} \\
L_{\mathrm{W}} & =\frac{1}{3} d \\
L_{\mathrm{B}} & =L_{\mathrm{N}}=\frac{1}{2} c \\
L_{\mathrm{O}} & =L_{\mathrm{S}}=0 \\
L_{\mathrm{C}} & =\frac{1}{2} h_{\mathrm{c}} .
\end{aligned}
$$

These are all shown in Figure 4. Equation (10) is exact only if the surface and bed are parallel.

Step 4 consists of applying the equations of statics to compute unknown reaction forces, assuming no inertial forces. Force equilibrium along $x$ requires that:

$$
F_{\mathrm{I}}-F_{\mathrm{W}}-F_{\mathrm{O}}-F_{\mathrm{C}}=0
$$

from which, up until a tensile crack opens the shear band:

$$
\begin{aligned}
\sigma_{x x} & =\frac{1}{2} \rho_{\mathrm{I}} g h_{\mathrm{c}}-\frac{1}{2} \rho_{\mathrm{W}} g d^{2} / h_{\mathrm{c}} \\
& =\frac{1}{2} \rho_{\mathrm{I}} g h_{\mathrm{c}}\left(1-\rho_{\mathrm{W}} d^{2} / \rho_{\mathrm{I}} h_{\mathrm{c}}^{2}\right)-\tau_{0}\left(c / h_{\mathrm{c}}\right) .
\end{aligned}
$$

Force equilibrium along $z$ requires that:

$$
F_{\mathrm{B}}-F_{\mathrm{S}}-F_{\mathrm{N}}=0
$$

from which:

$$
\begin{aligned}
\sigma_{z z} & =\rho_{\mathrm{I}} g \bar{h}-\rho_{\mathrm{W}} g d-\tau_{\mathrm{s}} h_{\mathrm{c}} / c \\
& =\rho_{\mathrm{I}} g \bar{h}\left(1-\rho_{\mathrm{W}} d / \rho_{\mathrm{I}} \bar{h}\right)-\tau_{\mathrm{s}}\left(h_{\mathrm{c}} / c\right) .
\end{aligned}
$$

Moment equilibrium about the $y$-axis requires that, up until a tensile crack opens the shear band:

$$
M_{y}+F_{\mathrm{C}} L_{\mathrm{C}}+F_{\mathrm{N}} L_{\mathrm{N}}+F_{\mathrm{W}} L_{\mathrm{W}}-F_{\mathrm{B}} L_{\mathrm{B}}-F_{\mathrm{I}} L_{\mathrm{I}}=0
$$

from which:

$$
\begin{gathered}
M_{y}=\frac{1}{2} w h_{\mathrm{c}}\left(\tau_{0}+\tau_{\mathrm{s}}\right)-\frac{1}{4} \rho_{\mathrm{I}} g w h_{\mathrm{c}}^{3}\left(1-\rho_{\mathrm{W}} d^{2} / \rho_{\mathrm{I}} h_{\mathrm{c}}^{2}\right) \\
+\frac{1}{6} \rho_{\mathrm{I}} g h_{\mathrm{c}}^{3}\left(1-\rho_{\mathrm{W}} d^{3} / \rho_{\mathrm{I}} h_{\mathrm{c}}^{3}\right)
\end{gathered}
$$

where bending moment $M_{y}$ causes bending creep at crosssection $w h_{\mathrm{c}}$ that leads to shear rupture and crevassing in the shear band at calving distance $c$ from the ice wall.

Step 5 consists of specifying the forces at cross-section $w h_{\mathrm{c}}$. Axial force $F_{\mathrm{C}}$ is obtained from Equations (7) and (14):

$$
F_{\mathrm{C}}=\frac{1}{2} \rho_{\mathrm{I}} g w h_{\mathrm{c}}^{2}\left(1-\rho_{\mathrm{W}} d^{2} / \rho_{\mathrm{I}} h_{\mathrm{c}}^{2}\right)-\tau_{0} w c .
$$

Shear force $F_{\mathrm{S}}$ is obtained from Equations (6) and (16):

$$
F_{\mathrm{S}}=\rho_{\mathrm{I}} g w c \bar{h}\left(1-\rho_{\mathrm{W}} d / \rho_{\mathrm{I}} \bar{h}\right)-\sigma_{z z} w c .
$$

Force $F_{\mathrm{S}}$ causes shear rupture in the shear band and force $F_{\mathrm{C}}$ causes the shear band to open into a crevasse. 


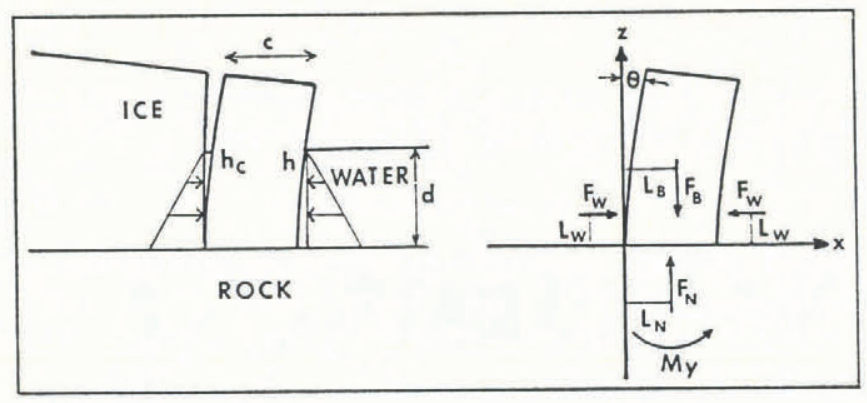

Fig. 5. Free-body diagrams for a slab at an ice wall after shear rupture detaches the slab. Left: boundary conditions; right: forces and moments.

Step 6 consists of isolating the slab after the crevasse opens and showing the forces and bending moments acting on it immediately prior to calving. As seen in Figure 2, the crevasse can separate most of the slab before it actually calves. The free-body diagram for the ice slab at this stage of bending creep is shown in Figure 5 .

Step 7 consists of major changes in the action and reaction forces if some assumptions are made. First, assume a thawed bed allows water to fill the crevasse to depth $d$, so that:

$$
F_{\mathrm{I}}=F_{\mathrm{W}}=\frac{1}{2} \rho_{\mathrm{W}} g w d^{2} .
$$

Secondly, downward penetration of the crevasse stops when $\sigma_{x x}=0$ at the crevasse tip, so that:

$$
F_{\mathrm{C}}=h_{\mathrm{c}} w \sigma_{x x}=0 .
$$

Thirdly, bending creep in numerous shear bands through length $c$ has inclined the ice slab an angle $\theta$ from the vertical, with $\theta$ increasing along $z$. Figure 6 shows similar triangles for which $\theta$ is the angle formed by the $z$-axis and the distance vector to point $x, z$ on the bending curve, and by velocity vectors $\mathbf{u}_{x}$ and $\mathbf{u}_{z}$ of point $x, z$. Therefore:

$$
\theta=x / z=\mathbf{u}_{z} / \mathbf{u}_{x}
$$

where forward displacement $x$ of the slab increases along $z$, with point $x, z$ on the slab having forward velocity $\mathbf{u}_{x}$ and downward velocity $\mathbf{u}_{z}$ due to bending creep.

Step 8 consists of solving the equations of static equilibrium for the free body in Figure 5. No net horizontal forces are present. Summing vertical forces:

$$
F_{\mathrm{B}}-F_{\mathrm{N}}=0 .
$$

Summing bending moments:

$$
M_{y}+F_{\mathrm{N}}\left(\frac{1}{2} c\right)-F_{\mathrm{B}}\left(\frac{1}{2} c+s\right)=0
$$

where $s$ is horizontal bending displacement $x$ at height $\frac{1}{2} \bar{h}$ of the centroid of the slab. Therefore, from Equation (23):

$$
s \approx \frac{1}{2} \bar{h} \theta \text {. }
$$

Entering Equations (3) and (4) into Equation (24) gives:

$$
\sigma_{z z}=F_{\mathrm{B}} / w c=\rho_{\mathrm{I}} g \bar{h}\left(1-\rho_{\mathrm{W}} d / \rho_{\mathrm{I}} \bar{h}\right) .
$$

Combining Equations (24) through (27) gives:

$$
M_{y}=F_{\mathrm{B}} s \approx-\frac{1}{2} \rho_{\mathrm{I}} g w c \bar{h}^{2} \theta\left(1-\rho_{\mathrm{W}} d / \rho_{\mathrm{i}} \bar{h}\right) .
$$

A calving criterion can be developed for the slab by

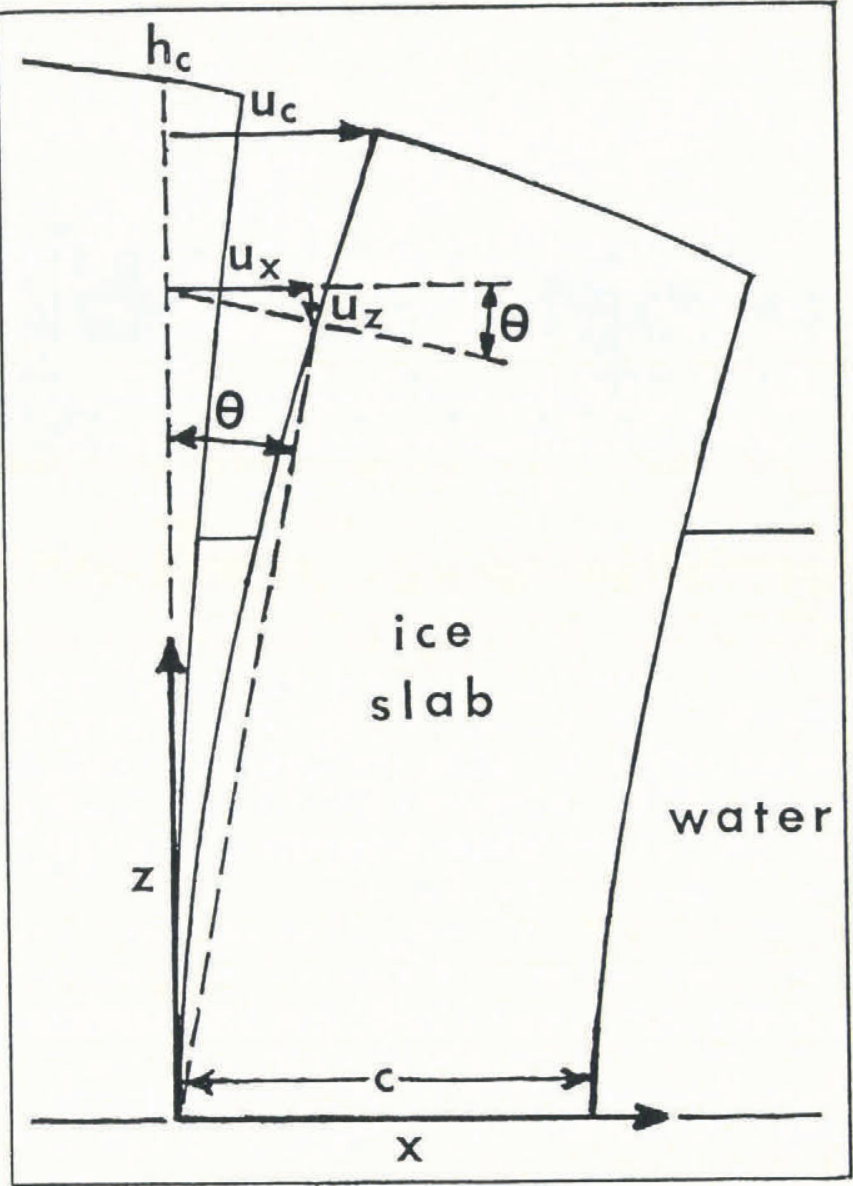

Fig. 6. A bending ice slab after $\tau_{\mathrm{s}}$ has caused shear rupture in a shear band and $\sigma_{x x}$ has opened a crevasse along the ruptured shear band. The relationship between the angle $\theta$ in the crevasses, point $x, z$ on the slab side of the crevasse and velocities $u_{x}, u_{z}$ at point $x, z$ is shown geometrically and is given by Equation (23). Note that $u_{x}=u_{\mathrm{c}}$ at the top of the crevasse.

entering $M_{y}$ into the flexure formula (Popov, 1952, p. 98102), and then deriving the differential equation for bending (Popov, 1952, p. 269-73).

In deriving the flexure formula, bending stresses normal to the beam cross-section, tensile on the convex side and compressive on the concave side, create an internal bending moment that exactly resists the external bending moment (Popov, 1952). The important concepts used to derive the flexure formula are: (1) beam geometry which establishes the variation of strain in the beam crosssection, (2) beam rheology which relates strain to stress, and (3) the laws of statics which locate the neutral axis and resisting moment at the beam cross-section. The flexure formula usually assumes elastic bending only, so that Hooke's law can be used to relate stress to strain. In this case, the flexure formula can be used to derive the differential equation for the elastic bending curve for a beam in static equilibrium (Popov, 1952, p. 269-73). When beam height $h$ along $z$ is large compared to beam length $c$ in bending direction $x$ and beam width $w$, a good approximation is:

$$
\frac{\mathrm{d}^{2} x}{\mathrm{~d} z^{2}}=\frac{M_{y}}{E I}
$$

where $E$ is the elastic modulus and $I=\frac{1}{12} w c^{3}$ is the 
rectangular moment of inertial for basal cross-sectional area $w c$ of the bending beam.

The counterpart to Equation (29) for creep bending when the beam is an ice slab in dynamic equilibrium is:

$$
\frac{\mathrm{d}^{2} \mathbf{u}_{x}}{\mathrm{~d} z^{2}}=\frac{M_{\mathrm{y}}}{\eta_{\mathrm{v}} I}
$$

where $\eta_{\mathrm{v}}$ is the viscoplastic viscosity of creep. Instead of relating stress to strain using Hooke's law, as was done in deriving Equation (29), Equation (30) is derived by relating stress to strain rate using Glen's law (Glen, 1955).

At the start of bending creep, Equation (18) is substituted into Equation (30), which is then integrated twice to give:

$$
\begin{gathered}
\mathbf{u}_{x}=\frac{h_{\mathrm{c}}}{2 \eta_{\mathrm{v}} c^{3}}\left[6 c\left(\tau_{0}+\tau_{\mathrm{s}}\right)-3 \rho_{\mathrm{I}} g h_{\mathrm{c}}^{2}\left(1-\rho_{\mathrm{W}} d^{2} / \rho_{\mathrm{I}} h_{\mathrm{c}}^{2}\right)\right. \\
\left.+2 \rho_{\mathrm{I}} g h_{\mathrm{c}}^{2}\left(1-\rho_{\mathrm{W}} d^{3} / \rho_{\mathrm{I}} h_{\mathrm{c}}^{3}\right)\right] z^{2}
\end{gathered}
$$

where $I=\frac{1}{12} w c^{3}$ is the rectangular moment of intertia for basal area $w c$ of the ice slab. At the top of the ice slab, $z=h_{\mathrm{c}}$ and $\mathbf{u}_{x}=u_{\mathrm{c}}$ is the maximum velocity of bending creep, so that:

$$
\begin{gathered}
u_{\mathrm{c}}=\frac{h_{\mathrm{c}}^{3}}{2 \eta_{\mathrm{v}} c^{3}}\left[6 c\left(\tau_{0}+\tau_{\mathrm{s}}\right)-3 \rho_{\mathrm{I}} g h_{\mathrm{c}}^{2}\left(1-\rho_{\mathrm{W}} d^{2} / \rho_{\mathrm{I}} h_{\mathrm{c}}^{2}\right)\right. \\
\left.+2 \rho_{\mathrm{I}} g h_{\mathrm{c}}^{2}\left(1-\rho_{\mathrm{W}} d^{3} / \rho_{\mathrm{I}} h_{\mathrm{c}}^{3}\right)\right] .
\end{gathered}
$$

When bending creep is ended by shear rupture, so that a fracture crevasse opens the shear band, Equation (28) is substituted into Equation (30), so that:

$$
\mathbf{u}_{x}=\frac{3 \rho_{\mathrm{I}} g \bar{h}^{2} \theta}{\eta_{\mathrm{v}} c^{2}}\left(1-\frac{\rho_{\mathrm{W}} \mathrm{d}}{\rho_{\mathrm{I}} \bar{h}}\right) z^{2} .
$$

The slab calves when $\mathbf{u}_{x}=u_{\mathrm{c}}$ measured at $z=h_{\mathrm{c}} \approx \bar{h}$ :

$$
u_{c}=\frac{3 \rho_{\mathrm{I}} g \bar{h}^{4} \theta}{\eta_{\mathrm{v}} c^{2}}\left(1-\frac{\rho_{\mathrm{W}} d}{\rho_{\mathrm{I}} \bar{h}}\right)=\frac{3 \rho_{\mathrm{I}} g \bar{h}^{2} \theta}{\eta_{\mathrm{v}}(c / \bar{h})^{2}}\left(1-\frac{\rho_{\mathrm{W}} d}{\rho_{\mathrm{I}} \bar{h}}\right)
$$

where $u_{\mathrm{c}}$ is the calving velocity and $c / \bar{h}$ is the calving ratio. The smaller the calving ratio, the better Equation (34) gives the calving rate.

Glen's law (Glen, 1955), used to compute $\eta_{\mathrm{v}}$, is:

$$
\dot{\epsilon}=\dot{\epsilon}_{0}\left(\tau / \sigma_{0}\right)^{n}=(\tau / A)^{n}
$$

where $\dot{\epsilon}$ is the effective strain rate, $\tau$ is the effective stress, $\dot{\epsilon}_{0}$ is the strain rate at plastic yield stress $\sigma_{0}, n$ is a viscoplastic creep exponent and $A$ is an ice-hardness parameter that depends on ice temperature and crystal fabric.

The calving criterion to be applied to the ice slab states that the slab calves when shear rupture occurs in the shear band at calving distance $c$ behind the ice wall. A fracture criterion for this situation requires that shear rupture occurs when maximum shear stress $\tau_{\mathrm{m}}=$ $\frac{1}{2}\left(\sigma_{1}-\sigma_{2}\right)$ reaches the viscoplastic yield stress $\sigma_{\mathrm{v}}$, where $\sigma_{1}$ and $\sigma_{2}$ are maximum and minimum principal stresses. This is the maximum shear-stress yield criterion. Setting $\dot{\epsilon}=\dot{\epsilon}_{\mathrm{m}}$ and $\tau=\tau_{\mathrm{m}}$, Equation (35) is plotted as $\dot{\epsilon}_{\mathrm{m}} / \dot{\epsilon}_{0}$ versus $\tau_{\mathrm{m}} / \sigma_{0}$ in Figure 7 to show how $\sigma_{\mathrm{v}}$ and $\eta_{\mathrm{v}}$ are obtained. Curves for all values of $n$ from $n=1$ for viscous creep to $n=\infty$ for plastic creep constitute the viscoplastic creep spectrum, and they all intersect at strain rate $\dot{\epsilon}_{0}$. In

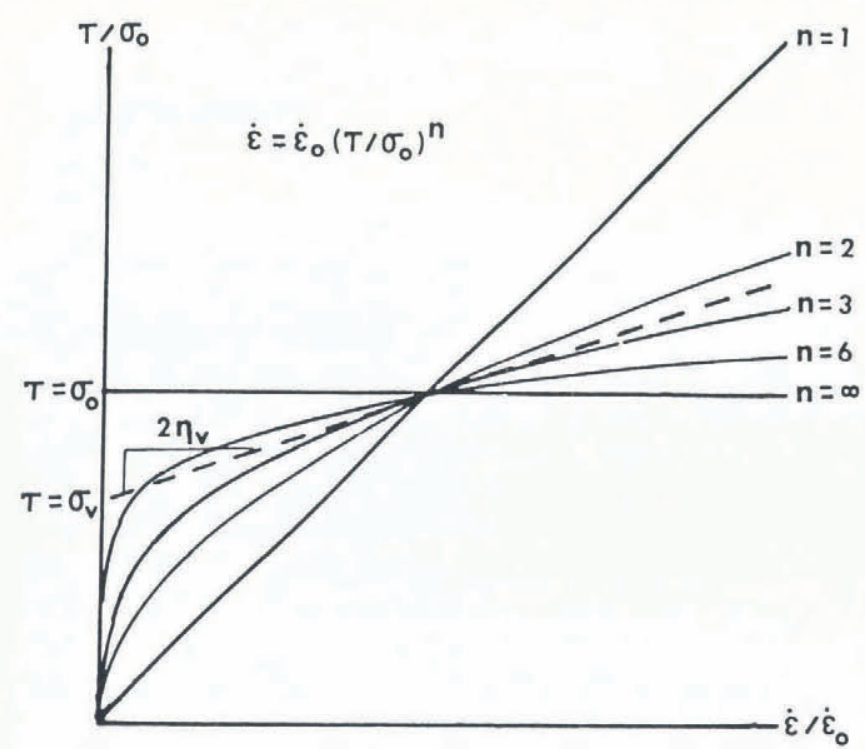

Fig. 7. The viscoplastic creep spectrum in ice. The tangent line (dashed) to a creep curve at strain rate $\dot{\epsilon}_{0}$ has a slope equal to twice the viscoplastic viscosity $\eta_{\mathrm{v}}$ and an intercept with the stress axis equal to the viscoplastic yield stress $\sigma_{\mathrm{v}}$, as shown for the $n=3$ creep curve (Hughes, 1983).

the critical strain-rate fracture criterion, fracture is most likely at $\dot{\epsilon}_{0}$, and the viscoplastic yield stress $\sigma_{\mathrm{v}}$ for fracture is obtained where straight lines tangent to the creep curves at $\dot{\epsilon}_{0}$ in Figure 7 intersect the stress axis. At this intersection, $\tau=\tau_{\mathrm{m}}=\sigma_{\mathrm{v}}$ and (Hughes, 1983):

$$
\frac{\sigma_{v}}{\sigma_{0}}=\frac{n-1}{n} \text {. }
$$

Viscoplastic viscosity $\eta_{\mathrm{v}}$ at the moment of fracture is half the slope of the tangent line at $\dot{\epsilon}_{0}$ for a given value of $n$ (Hughes, 1983):

$$
\begin{aligned}
\eta_{\mathrm{v}} & =\frac{1}{2}\left(\mathrm{~d} \tau_{\mathrm{m}} / \mathrm{d} \dot{\varepsilon}\right)=\frac{1}{2} \sigma_{0}^{n} / n \dot{\varepsilon} \tau_{\mathrm{m}}^{n-1} \\
& =\frac{1}{2} A^{n} / n \tau_{\mathrm{m}}^{n-1}=\frac{1}{2} \tau_{\mathrm{m}} / n \dot{\varepsilon}_{\mathrm{m}}=\eta_{\mathrm{m}} / n
\end{aligned}
$$

where $2 \eta_{\mathrm{m}}=\tau_{\mathrm{m}} / \dot{\epsilon}_{\mathrm{m}}$ and $\eta_{\mathrm{m}}$ is the Newtonian viscosity for purely viscous flow. In the glaciological literature, $\eta_{\mathrm{m}}$ is often called the "effective viscosity" at effective stress $\tau$. It is the slope of a straight line from the origin, $\dot{\epsilon}=\tau=0$, that intersects a creep curve in Figure 7 at $\tau$ for a given $n$. A tangent line to the creep curve is a better measure of the physical property called viscosity. As seen in Figure 7, the tangent line at $\dot{\epsilon}_{0}$ gives both the viscoplastic yield stress by its intercept with the stress axis and the viscoplastic viscosity by half its slope.

\section{RESULTS}

In applying Equation (34) to calving ice walls, such as the one in Figure 2, a question arises. Should $\theta$ be measured when the crevasse first opens, in which case $\theta$ is about $6^{\circ}$ $(0.1 \mathrm{rad})$, as measured by the forward tilt of the left side of the crevasse; or should $\theta$ be measured when the slab actually calves, in which case $\theta$ is about $18^{\circ}(0.3 \mathrm{rad})$ as measured by the forward tilt of the right side of the crevasse? As seen in Figure 8, other crevasses open behind 


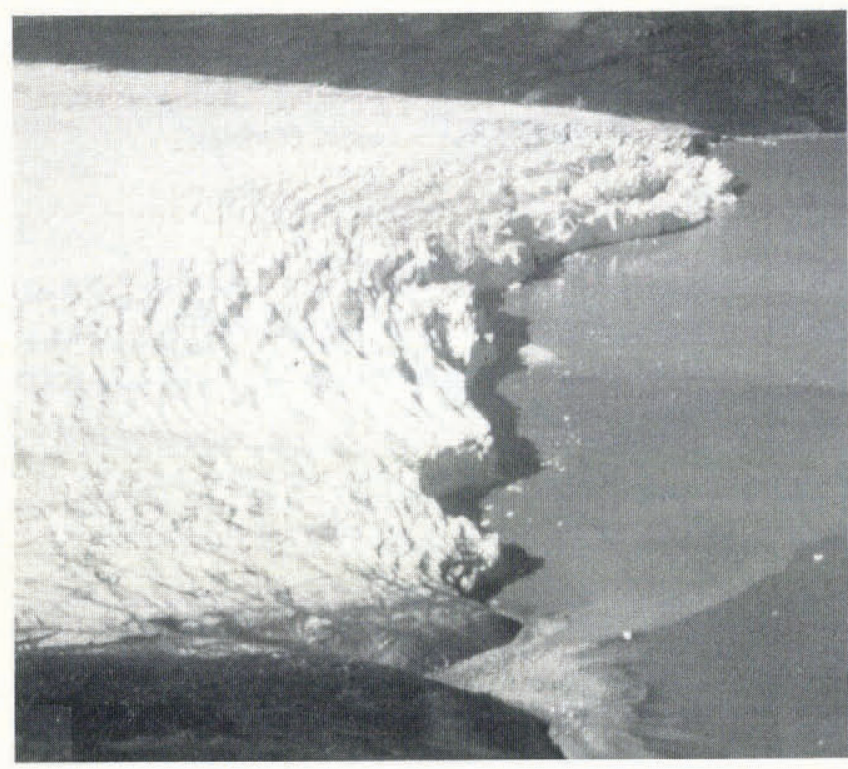

Fig. 8. Transverse crevasses behind the ice wall of a tidewater outlet glacier in Greenland.

the primary crevasse before calving, so $\theta$ should apply to the calving event itself.

A second question concerns the calving ratio $c / h$. For convenience, let $h=\bar{h}=h_{\mathrm{c}}$. Is $c / h$ a function of total ice thickness $h$, or just ice thickness $h_{\mathrm{w}}$ above water? Both possibilities exist in Figure 2. Also, does $c / h$ depend on water depth $d$ through flotation ratio $\left(\rho_{\mathrm{W}} / \rho_{\mathrm{I}}\right) d / h$ for the ice wall? Figure 2 is for $d=0$, so it provides no answers to these questions.

A third question concerns the value of viscoplastic viscosity $\eta_{\mathrm{v}}$ to be used in Equation (34). If creep in the bending slab is primarily in shear bands, not between shear bands, then creep by easly glide, not hard glide, dominates. Paterson (1981, p. 41) gave $\eta_{\mathrm{m}}=$ $8 \times 10^{13} \mathrm{~kg} \mathrm{~m}^{-1} \mathrm{~s}^{-1}$ for the minimum creep rate (hard glide) and $\sigma_{0}=1$ bar as the plastic yield stress, for which $\sigma_{\mathrm{v}}=0.67 \mathrm{bar}$ for $n=3$ in Equation (36). Hughes and Nakagawa (1989) reported that the creep rate increases ten-fold in shear bands (easy glide), for which $\eta_{\mathrm{m}}=$ $8 \times 10^{12} \mathrm{~kg} \mathrm{~m}^{-1} \mathrm{~s}^{-1}$.

These questions can be addressed using data from 12 calving tide-water glaciers in Alaska (Brown and others, 1982). Table 1 lists the glaciers and values of $h, h_{\mathrm{w}}, d$ and $\bar{u}_{\mathrm{c}}$ for each one, where $\bar{u}_{\mathrm{c}}$ is the mean annual calving rate that can be compared with $u_{\mathrm{c}}$ in Equation (34). Figure 2 is consistent with four expressions for $c$ in Equation (34); a linear dependence on $h$ :

$$
c / h=0.4
$$

a linear dependence on $h_{\mathrm{w}}$ :

$$
c / h_{\mathrm{w}}=c /(h-d)=0.4
$$

a linear dependence on $\left(\rho_{\mathrm{W}} / \rho_{\mathrm{I}}\right) d / h$ :

$$
c / h=0.4-0.35\left(\rho_{\mathrm{W}} / \rho_{\mathrm{I}}\right) d / h ;
$$

and a parabolic dependence on $\left(\rho_{\mathrm{W}} / \rho_{\mathrm{I}}\right) d / h$ :

$$
(c / h)^{2}=(0.22) /\left[\left(\rho_{\mathrm{W}} / \rho_{\mathrm{I}}\right) d / h\right] .
$$

Values of $c / h$ in Equations (40) and (41) are obtained by
Table 1. Average ice thickness $h$, ice height above water $h_{\mathrm{w}}$, water depth $d$ and mean annual calving rate $\bar{u}_{\mathrm{c}}$ at the ice walls of 12 Alaskan tide-water glaciers (Brown and others, 1982)

\begin{tabular}{lrrrr} 
Glacier & \multicolumn{1}{c}{$h$} & $h_{\mathrm{w}}$ & $d$ & $\bar{u}_{\mathrm{c}}$ \\
& $\mathrm{m}$ & $\mathrm{m}$ & $\mathrm{m}$ & $\mathrm{m} \mathrm{a}^{-1}$ \\
& & & & \\
\hline & & & & \\
McCarty & 42 & 30 & 12 & 600 \\
Harvard & 104 & 68 & 36 & 1080 \\
Yale & 222 & 69 & 153 & 3500 \\
Meares & 90 & 59 & 31 & 1010 \\
Columbia & 161 & 86 & 75 & 2185 \\
Tyndall & 113 & 49 & 64 & 1740 \\
Hubbard & 172 & 92 & 80 & 2630 \\
Grand Pacific & 62 & 44 & 18 & 220 \\
Margerie & 75 & 60 & 15 & 463 \\
Johns Hopkins & 126 & 70 & 56 & 2290 \\
Muir & 160 & 60 & 100 & 3700 \\
South Sawyer & 234 & 48 & 186 & 3200 \\
& & & & \\
\hline
\end{tabular}

setting $u_{\mathrm{c}}=\bar{u}_{\mathrm{c}}$ in Equation (34) and solving for $c / h$ :

$$
\left(\frac{c}{h}\right)^{2}=\frac{3 \rho_{\mathrm{I}} g h^{2} \theta}{\eta_{\mathrm{v}} \bar{u}_{\mathrm{c}}}\left(1-\frac{\rho_{\mathrm{W}} d}{\rho_{\mathrm{I}} h}\right) .
$$

Figures 9 and 10 show the respective linear and logarithmic plots of $c / h$ obtained from Equation (42), versus $\left(\rho_{\mathrm{W}} / \rho_{\mathrm{I}}\right) d / h$ in Equations (40) and (41). The linear plot is preferred because it can include $c / h=0.4$ at $d=0$, from Figure 2 .

Table 3 shows results from entering Equations (38) through (41) into Equation (34). Ideally, $u_{\mathrm{c}} / \bar{u}_{\mathrm{c}}=1.00$. Reasonable approximations of this ideal are attained for

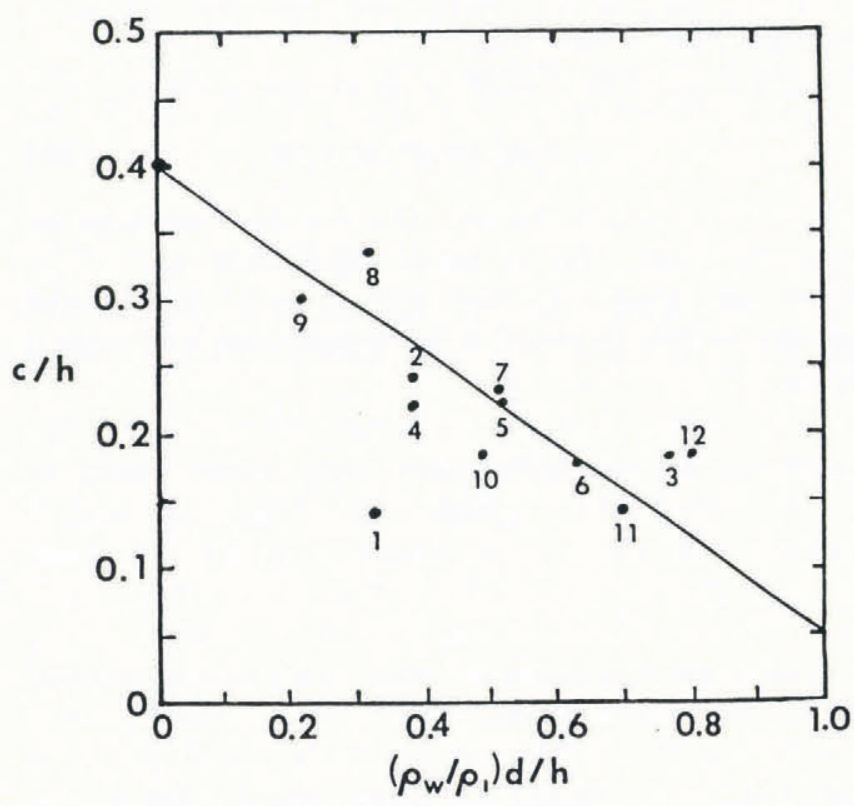

Fig. 9. A linear dependence of calving ratio $c / h$ on buoyancy ratio $\left(\rho_{\mathrm{W}} / \rho_{\mathrm{I}}\right) d / h$ for the ice wall in Figure 2 and the 12 tide-water glaciers in Tables 1 and 2. 


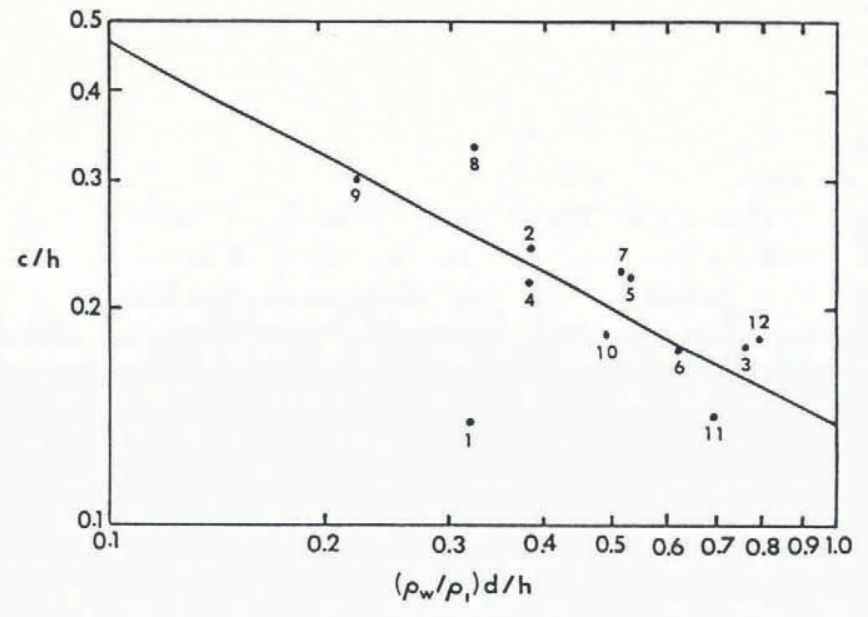

Fig. 10. A logarithmic dependence of calving ratio $c / h$ on buoyancy ratio $\left(\rho_{\mathrm{W}} / \rho_{\mathrm{I}}\right) d / h$ for the ice wall in Figure 2 and the 12 tide-water glaciers in Tables 1 and 2. most of the 12 glaciers if $\theta=0.3 \mathrm{rad}$ and bending creep of the ice wall is controled by $\eta_{\mathrm{m}}=8 \times 10^{12} \mathrm{~kg} \mathrm{~m}^{-1} \mathrm{~s}^{-1}$ for easy glide within shear bands, $\eta_{\mathrm{m}}=8 \times 10^{13} \mathrm{~kg} \mathrm{~m}^{-1} \mathrm{~s}^{-1}$ for hard glide between shear bands, or for $\eta_{\mathrm{m}}=$ $4 \times 10^{13} \mathrm{~kg} \mathrm{~m}^{-1} \mathrm{~s}^{-1}$ for a combination of easy and hard glide within and between shear bands. In fact, $u_{\mathrm{c}} / \bar{u}_{\mathrm{c}}=$ $1.03 \pm 0.01$ averaged for all the $u_{\mathrm{c}}$ values in Table 2 . These results are summarized in Table 3 . The same results are obtained for $\theta=0.1 \mathrm{rad}$ and $\eta_{\mathrm{v}}=\frac{1}{3} \eta_{\mathrm{m}}$ for $n=3$ in Equation (37). However, Equation (30), and therefore Equation (34), are exact only for $n=1$ in Equation (37) (Popov, 1952, p. 109-13).

\section{DISGUSSION}

Results in Table 2 are consistent with both easy glide within shear bands and hard glide between shear bands

Table 2. A comparison of theoretical calving rates $u_{\mathrm{c}}$ and observed mean annual calving rates $\bar{u}_{\mathrm{c}}$ from the ice walls of Alaskan tide-water glaciers

\begin{tabular}{|c|c|c|c|c|c|c|c|c|}
\hline \multirow[t]{3}{*}{ Glacier } & \multicolumn{2}{|c|}{ Equation (38) } & \multicolumn{2}{|c|}{ Equation (39) } & \multicolumn{2}{|c|}{ Equation (40) } & \multicolumn{2}{|c|}{ Equation (41) } \\
\hline & $u_{\mathrm{c}}$ & $u_{\mathrm{c}} / \bar{u}_{\mathrm{c}}$ & $u_{\mathrm{c}}$ & $u_{\mathrm{c}} / \bar{u}_{\mathrm{c}}$ & $u_{\mathrm{c}}$ & $u_{\mathrm{c}} / \bar{u}_{\mathrm{c}}$ & $u_{\mathrm{c}}$ & $u_{\mathrm{c}} / \bar{u}_{\mathrm{c}}$ \\
\hline & $\mathrm{m} \mathrm{a}^{-1}$ & & $\mathrm{ma}^{-1}$ & & $\mathrm{ma}^{-1}$ & & $\mathrm{~m} \mathrm{a}^{-1}$ & \\
\hline McCarty & 241 & 0.40 & 94 & 0.02 & 137 & 0.23 & 120 & 0.20 \\
\hline Harvard & 1333 & 1.23 & 624 & 0.58 & 895 & 0.83 & 808 & 0.74 \\
\hline Yale & 2316 & 0.66 & 480 & 1.38 & 6274 & 1.79 & 2800 & 0.80 \\
\hline Meares & 1001 & 0.99 & 468 & 0.46 & 670 & 0.66 & 604 & 0.60 \\
\hline Columbia & 2504 & 1.15 & 1753 & 0.80 & 2242 & 1.03 & 2046 & 0.94 \\
\hline Tyndall & 947 & 0.64 & 1018 & 0.58 & 1386 & 0.94 & 942 & 0.64 \\
\hline Hubbard & 2858 & 1.09 & 2000 & 0.76 & 2822 & 1.07 & 2334 & 0.88 \\
\hline Grand Pacific & 521 & 2.37 & 208 & 0.94 & 299 & 1.36 & 266 & 1.20 \\
\hline Margerie & 875 & 1.89 & 273 & 0.60 & 400 & 0.86 & 308 & 0.66 \\
\hline Johns Hopkins & 1610 & 0.70 & 1043 & 0.46 & 1479 & 0.65 & 1254 & 0.54 \\
\hline Muir & 1567 & 0.42 & 2234 & 0.60 & 3007 & 0.81 & 1718 & 0.46 \\
\hline South Sawyer & 2245 & 0.70 & 10690 & 3.34 & 7190 & 2.25 & 2820 & 0.88 \\
\hline
\end{tabular}

Table 3. Average calving velocity ratios $u_{\mathrm{c}} / \bar{u}_{\mathrm{c}}$ computed for combinations of wall bending angles $\theta$ and ice viscosities $\eta_{\mathrm{m}}$ and $\eta_{\mathrm{v}}$
Equation (38)
Equation (39)
Equation (40)
Equation (41)

$\begin{array}{lcccc}\text { Average }\left(u_{\mathrm{c}} / \bar{u}_{\mathrm{c}}\right) & 1.02 & 1.04 & 1.04 & 0.71 \\ \begin{array}{l}\theta=18^{\circ}=0.3 \mathrm{rad} \\ \eta_{\mathrm{m}}\left(\mathrm{kg} \mathrm{m}^{-1} \mathrm{~s}^{-1}\right)\end{array} & 8 \times 10^{12} & 4 \times 10^{13} & 8 \times 10^{13} & 4 \times 10^{13} \\ \theta=6^{\circ}=0.1 \mathrm{rad} & & & & \\ \eta_{\mathrm{v}}\left(\mathrm{kg} \mathrm{m}^{-1} \mathrm{~s}^{-1}\right) & 8 / 3 \times 10^{12} & 4 / 3 \times 10^{13} & 8 / 3 \times 10^{13} & 4 / 3 \times 10^{13}\end{array}$


contributing to bending creep in the ice slab. This was confirmed by relating bending creep to ice fabrics in and between shear bands behind the calving ice wall on Deception Island (Hughes and Nakagawa, 1989). The calving ratio was $c / h \approx 0.3$, but the ends of crevasses at calving distance $c$ behind the ice wall experienced compression from converging ice flow. This violated the assumption that end effects did not exist or could be ignored. The assumption is valid for the ice wall in Figure 2 , where $c / h=0.4$. Field studies on tide-water glaciers are needed to determine the dependence, if any, of $c / h$ on water buoyancy at the ice wall, as measured by $\left(\rho_{\mathrm{W}} / \rho_{\mathrm{I}}\right) d / h$.

As illustrated by the Greenland tide-water glacier in Figure 8, a series of transverse crevasses, about equally spaced, open and widen toward the calving ice wall. If this crevassed section of the glacier became afloat, columnar slabs would calve if $c / h<1$ and tabular icebergs would calve if $c / h>1$. Water would fill the crevasses up to sea level. When water in crevasses between slabs reaches the flotation depth, the crevassed section becomes afloat if water continues to deepen, and the forward bending creep of a grounded ice wall also includes the upward flexural creep of a floating ice shelf. Reeh (1968) analyzed upward flexural creep of this kind and found that calving would occur at $c / h \approx 0.5$ where $\tau_{\mathrm{s}}=\tau_{\mathrm{m}}=\frac{1}{2}\left(\sigma_{1}-\sigma_{2}\right)$ is maximized, but that calving could also occur at $c / h \approx 1.0$ where $\sigma_{x x}=\sigma_{\mathrm{m}}$ was a maximum tensile stress at the top of the flexural arch. In finite-element modeling of these stresses, however, Fastook and Schmidt (1982) determined that water must at least partly fill the crevasses if they were to migrate downward through the ice and result in slab or tabular calving.

The similarities and differences between forward bending of an ice wall and upward arching of an ice shelf are compared in Figure 11. The main similarity between the two is that both are caused by an asymmetrical imbalance between lithostatic and hydrostatic horizontal gravity forces in ice and water at the calving ice cliff. This allows upwardly curving shear bands to develop in both cases. The main difference between the two is that removal of basal traction when ice floats allows forward bending at the ice cliff also to include downward bending of basal ice, bending below the buoyancy depth of ice, so that isostatic compensation requires upward arching of ice behind the ice cliff.

If the dependence between the calving ratio $c / h$ and

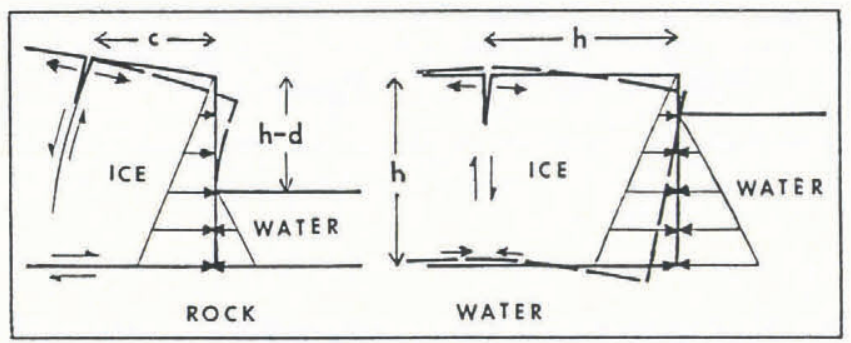

Fig. 11. A comparison between forward bending of an ice wall and upward arching of an ice shelf due to asymmetry between lithostatic pressure in ice and hydrostatic pressure in water at the calving front. buoyancy ratio $\left(\rho_{\mathrm{W}} / \rho_{\mathrm{I}}\right) d / h$ depicted in Figures 9 and 10 is correct, then calving slabs get relatively taller and thinner as water gets deeper prior to flotation of the slabs. If backward calving exceeds the forward velocity of a tide-water glacier, its calving ice wall retreats, often into deeper water if the glacier occupies a foredeepened fiord. Hence, $c / h$ will be reduced and, if the section of the glacier weakened by transverse crevasses, as depicted in Figure 8, becomes afloat, tabular calving for which $c / h \approx 1$ becomes possible in addition to slab calving for which $c / h \ll 1$. However, tabular icebergs released from this floating section of the glacier will be weakened at intervals where shear rupture in vertically bending shear bands allowed transverse crevasses to open. Flexural arching can therefore be accommodated by shear in these shear bands, as depicted in Figure 12. Since ice slabs are only weakly held together across these shear bands, the tabular iceberg may disintegrate by slab calving even while it is being released from the floating ice front. Epprecht (1987) described this disintegration for blocks

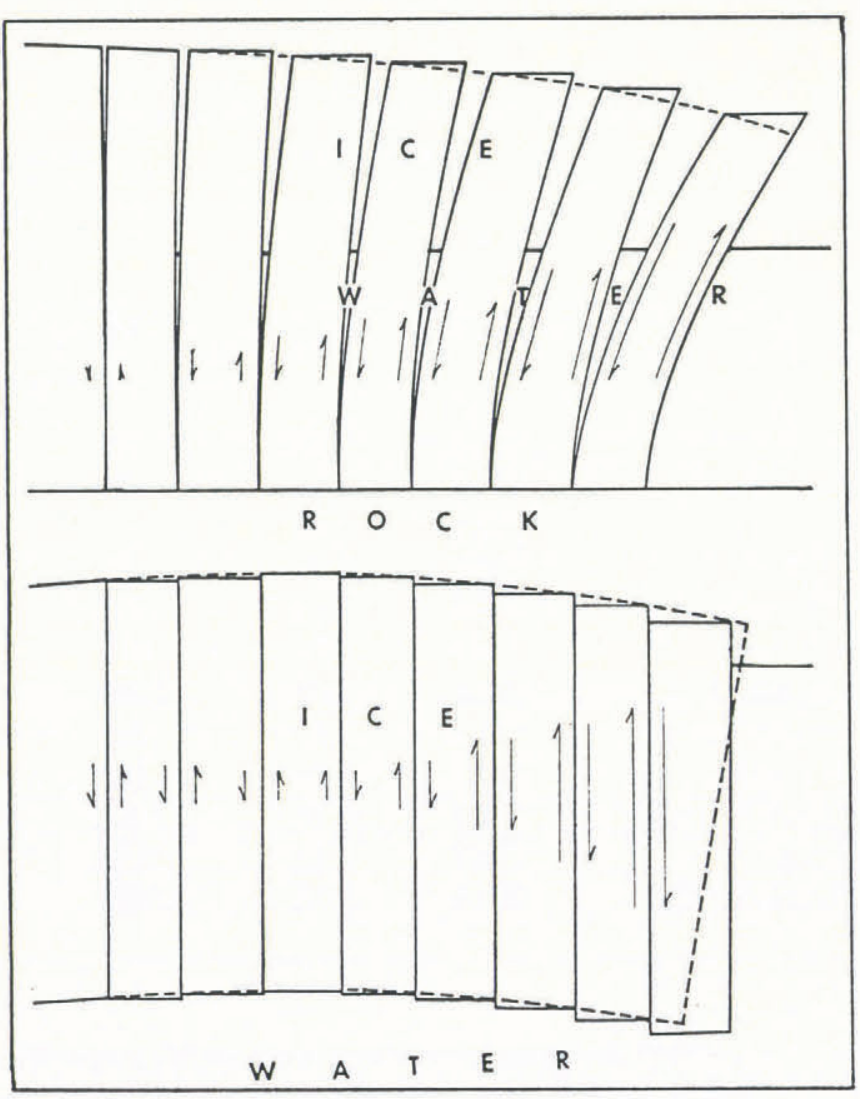

Fig. 12. A comparison between forward bending of an ice wall and upward arching of an ice shelf due to shear displacements between ice slabs. Top: behind the ice wall, $\tau_{\mathrm{s}}=\sigma_{x x}=0$ across crevasses. Widening of the crevasses is due to increasing forward bending of ice slabs between crevasses, so that extending flow at the ice surface is caused by bending stress $\tau_{\mathrm{s}}$ within each slab, not by $\sigma_{x x}$ within slabs, and this produces an increasing surface slope (dashed line). Bottom: in the ice shelf, upward arching is caused by shear within shear bands that close after the glacier becomes afloat. This shear relieves forward bending (dashed line) caused by $\sigma_{x x}$ that is tensile on the top surface and compressive on the bottom surface, as shown in Figure 11. 
$\mathrm{H}, \mathrm{J}$ and $\mathrm{K}$, tabular icebergs released from the north side of Jakobshavns Isbræ $\left(69^{\circ} 10^{\prime} \mathrm{N}, 50^{\circ} 10^{\prime} \mathrm{W}\right)$ in Greenland. Since $c / h \approx 1$ for these blocks, they began to rotate as they detached from the ice front: "During the rotation of block $\mathrm{H}$, more crevasses opened in the newly separated section of the glacier and, as a result, blocks $\mathrm{J}$ and $\mathrm{K}$ became more free (Fig. 4). These then fell over, one after the other, like falling dominoes.... Within $7 \mathrm{~min}$, not only did the part which had become separated from the glacier by the main fissure disintegrate into blocks, but these blocks had also toppled over. Afterwards, they all lay as large white slabs, several hundred meters across, closely packed together in the fjord (Fig. 2). Their surfaces were relatively smooth and very clean." The calving section of Jakobshavns Isbræ is shown in Figure 13. It consists of ice walls at the north and south sides that become an ice shelf in the center as water deepens along the calving front.

\section{CONGLUSIONS}

A possible decrease in claving ratio $c / h$ with increasing water depth (Figs 9 and 10), forward bending and upward arching both related to shear bands (Fig. 12) and the calving description by Epprecht (1987) for Jakobshavns Isbræ (Fig. 13) raise the possibility that Equation (34) may be a general calving law that has broad applications to all calving glaciers. In a private letter, A. Post (21 June 1990) stated that he recognized four kinds of calving from Alaskan tide-water glaciers. All four may be represented in USGS photograph number 87V2-058 of Miles Glacier, supplied by Post and reproduced here as Figure 14:

1. Normal slab calving. The ice wall stands on dry land $(d=0)$ or in shallow water $(d<<h)$ and may be frozen to the bed. In this case, on Deception Island, $\alpha \approx 0.3$ near the ice wall due to bending shear and $\alpha \approx 0.06$ further upslope due to bed traction (Hughes, 1989). Slabs the height of the ice wall, some tens of meters wide, and under

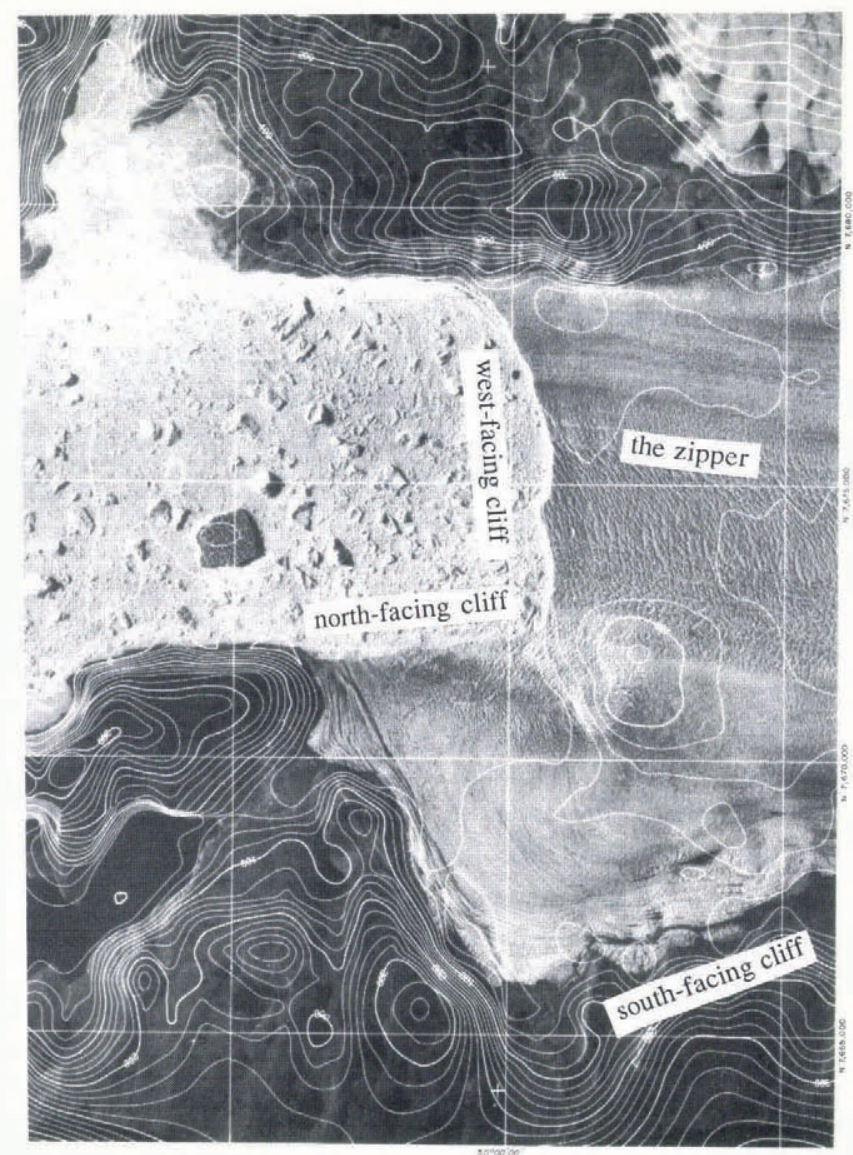

Fig. 13. Calving from Jakobshavns Isbre, Greenland (orthophotograph by KUCERA International, Inc., with elevation contours in meters based on photogrammetric measurements by $H$. Brecher).

$10 \mathrm{~m}$ thick calve at irregular intervals. Normal slab calving seems to be active on the photograph left side of the calving front of Miles Glacier. Post called this "steady-state" calving.

2. Unstable recessional calving. The calving rate exceeds the

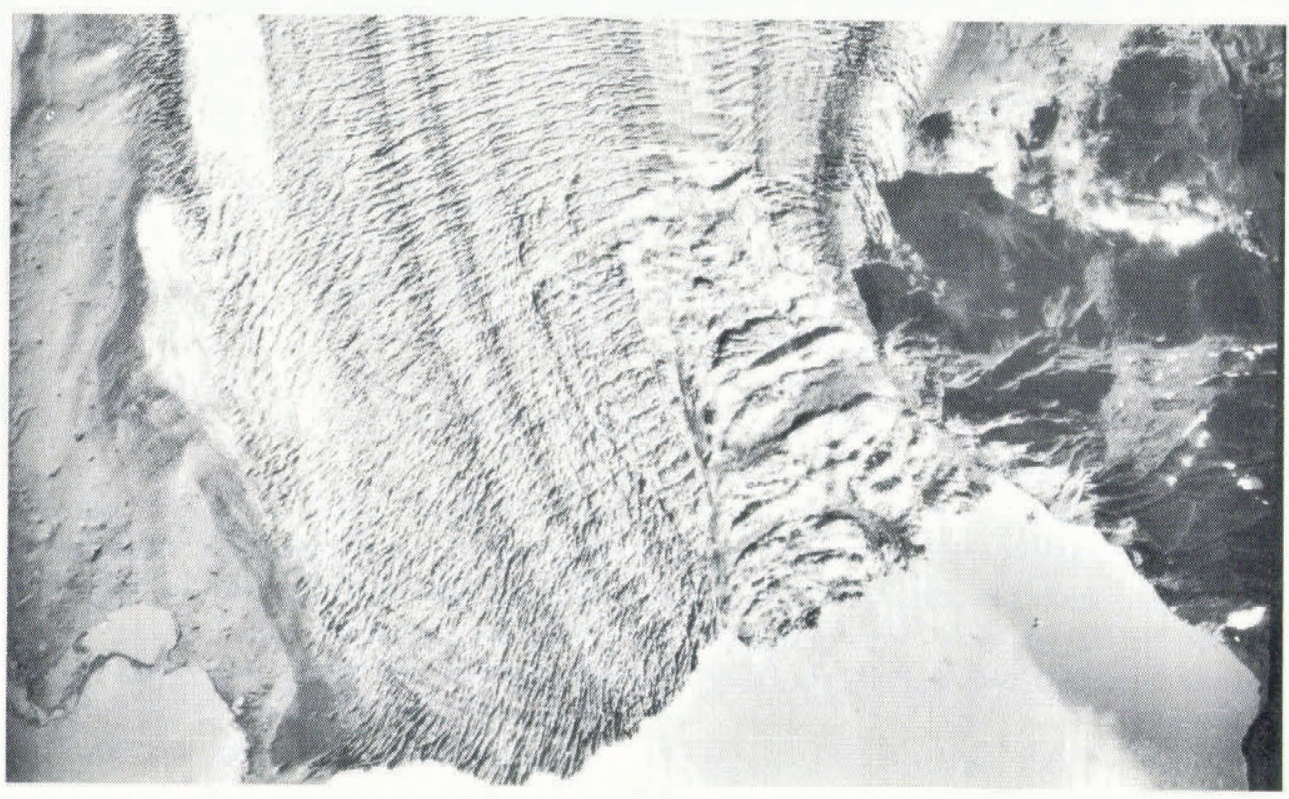

Fig. 14. Calving from Miles Glacier, Alaska (U.S.G.S. photograph 87V2-058, supplied by A. Post). 
ice velocity, causing an ice wall standing in water to retreat on a bed that slopes downward inland, thereby reducing the lithostatic overburden of ice on the bed $\left(d \rightarrow h \rho_{\mathrm{I}} / \rho_{\mathrm{W}}\right)$. This increases $h$ and reduces $\alpha$ near the ice wall in positive feed-back, so that normal slab calving is replaced by accelerated calving of thinner slabs that may create a calving bay if the calved slabs can be evacuated faster than the calving rate. Unstable recessional calving seems to be active on the photograph right side of the calving front of Miles Glacier. Post said a "retracted stable position" would re-establish normal slab calving at or near the head of tide water if the downsloping bed sloped upward further inland.

3. Sudden tabular calving. A large tabular section of the glacier suddenly and uniformly becomes uncoupled from the bed, probably due to a build-up of basal hydrostatic pressure to the flotation pressure $\left(d=h \rho_{\mathrm{I}} / \rho_{\mathrm{W}}\right)$. The large transverse rift at the rear of the calving section on the photograph right side of Miles Glacier could have released this section as a single tabular iceberg if Miles Glacier had been floating. Post described these calving events as being virtually identical to the calving of tabular icebergs from the floating front of Jakobshavns Isbræ. If the planar dimensions of the tabular section exceed its thickness, a tabular iceberg moves away from the ice front intact. Otherwise, it rears up on one side, rolls over and disintegrates completely within minutes.

4. Frequent buoyancy calving. Large sections of the ice front calve frequently when they become fully buoyant $\left(d>h \rho_{\mathrm{I}} / \rho_{\mathrm{W}}\right)$, while other grounded sections remain intact $\left(d<h \rho_{\mathrm{I}} / \rho_{\mathrm{W}}\right)$. These two conditions seem to apply to the photograph right side and the photograph left side, respectively, of Miles Glacier. For other tide-water glaciers, Post observed this calving process when the calving front is retreating into water up to $400 \mathrm{~m}$ or more in depth, and it seems to be the dominant form of calving from Columbia Glacier during the current rapid retreat. However, water in front of Miles Glacier is not this deep.

All of these four kinds of calving might be accommodated by the bending-shear mechanism quantified in Equation (34). The variables in this equation, $h, d, c$ and $\theta$, with $\alpha \approx \theta$ at the calving front, determine the calving velocity $u_{c}$. They have been observed by Post to be important, and they seem to have at least the correct qualitative relationships to observed calving rates. Data are insufficient to determine whether Equation (34) is a reliable quantitative expression for calving rates along the great variety of calving fronts provided by Jakobshavns Isbræ. However, it is clear that calving events are associated with new crevasses along the calving front and within one or two ice thicknesses behind the calving front that have no apparent relationship to older crevasses formed far upstream and carried passively to the calving front (unpublished photogrammetric measurements by $\mathrm{P}$. Prescott). This argues in favor of a local calving mechanism linked to the bending force and the bending moment at the calving front.

Some obvious features of this analysis should be emphasized. First, ablation at the ice wall is ignored. Ablation melts back the ice wall during bending shear, so the ice wall does not lean forward as much as it bends forward and may even lean backward. Ablation reduces $s$ in Equation (25), and $\theta$ in Equation (26) is the forward bending angle of the opening crevasse, not of the ice wall (see Fig. 6). Secondly, the ice wall is on a flat bed, so extending flow due to ice riding up on to a terminal moraine is not considered. Instead, extending flow is caused by $\sigma_{x x}$ in Equation (14) prior to shear bands becoming transverse crevasses, and by bending creep causing transverse crevasses to widen toward the calving ice wall (see Fig. 12, top). Thirdly, steepening of surface slope $\alpha$ toward the calving ice wall is primarily due to the widening of transverse crevasses by increasing bending creep (see Fig. 12, top), and this increase of $\alpha$ increases the forward ice velocity and the backward calving rate. Fourthly, downward calving of ice slabs requires either crushing or ablating ice at the base of the ice wall. However, these mechanisms do not control the calving rate; see Hughes and Nakagawa (1989). Fifthly, the calving rate given by Equation (34) is most reliable when the calving ratio $c / h$ and viscoplastic exponent $n$ are both small; ideally, $c / h \ll<1$ and $n=1$. Since $0.1<c / h<0.4$ is observed for ten tide-water glaciers and $n=3$ for ice, Equation (34) only gives approximate calving rates. Use of Equation (34) is even more problematic, given the ambiguities in specifying $\eta_{\mathrm{v}}$ and $\theta$. Even so, it has a foundation in theory and in observation.

A less obvious constraint on the bending-creep calving mechanism is the time needed to form a shear band. In laboratory creep experiments, about $25 \mathrm{~d}$ were needed when $\tau_{\mathbf{s}}$ was about 1 bar (Hughes and Nakagawa, 1989). This time constraint can be illustrated by calving from Columbia Glacier, for which $u_{\mathrm{c}}=7 \mathrm{~m} \mathrm{~d}^{-1}, h=160 \mathrm{~m}$ and $c / h=0.22$, so that an ice slab having $c=35 \mathrm{~m}$ calves every $5 \mathrm{~d}$. This means that bending creep must begin about $210 \mathrm{~m}$ behind the calving front if a shear band is to fracture by shear rupture $35 \mathrm{~m}$ behind the calving front.

\section{ACKNOWLEDGEMENTS}

I thank A. Post for sharing his insights on calving from tide-water glaciers, R. Hooke for comments on an earlier version of this manuscript and P. Prescott for sharing his unpublished photogrammetric measurements of surface elevations, slopes, velocities and strain rates along the calving front of Jakobshavns Isbræ. This work was funded by U.S. National Science Foundation grant DPP8400886 and Battelle, PNL, subcontract 017112-A-Bl.

\section{REFERENCES}

Andersen, B.G. 1981. Late Weichselian ice sheets in Eurasia and Greenland. In Denton, G. H. and T.J. Hughes, eds. The last great ice sheets. New York, etc., Wiley-Interscience, 1-65.

Andrews, J. T. 1973. The Wisconsin Laurentide ice sheet: dispersal centers, problems of rates of retreat, and climatic implications. Arct. Alp. Res., 5(3), 185-199.

Bindschadler, R. A. and L. A. Rasmussen. 1983. Finitedifference model predictions of the drastic retreat of 
Columbia Glacier, Alaska. U.S. Geol. Surv. Prof. Pap. 1258-D.

Brecher, H., M. Nakagawa and T. Hughes. 1976. Volcanic eruptions and the stability of glaciation on Deception Island, Antarctica. In Gonzales Ferran, O., ed. Proceedings of the Symposium on "Andean and Antarctic Volcanology Problems" (Santiago, Chile, September 1974). Rome, International Association of Volcanology and Chemistry of the Earth's Interior, 59-77.

Brown, C. S., M.F. Meier and A. Post. 1982. Calving speed of Alaska tidewater glaciers, with application to Columbia Glacier. U.S. Geol. Surv. Prof. Pap. 1258-C.

Carbonnell, M. and A. Bauer. 1968. Exploitation des couvertures photographiques aériennes répétées du front des glaciers vêlant dans Disko Bugt et Umanak Fjord, Juin-Juillet, 1964. Medd. Gronl., 173(5).

Doake, C.S.M. and D.G. Vaughan. 1991. Rapid disintegration of the Wordie Ice Shelf in response to atmospheric warming. Nature, 350(6316), 328-330.

Echelmeyer, K. and W. D. Harrison. 1990. Jakobshavns Isbræ, West Greenland: seasonal variations in velocity - or lack thereof. F. Glaciol., 36(122), 82-88.

Epprecht, W. 1987. A major calving event of Jakobshavns Isbræ, West Greenland, on 9 August 1982. J. Glaciol., 33(114), 169-172.

Fastook, J.L. 1984. West Antarctica, the sea-level controlled marine instability; past and future. In Hansen, J.E. and T. Takahashi, eds. Climate processes and climate sensitivity. Washington, DC, American Geophysical Union, 275-287.

Fastook, J. L. and W. F. Schmidt. 1982. Finite element analysis of calving from ice fronts. Ann. Glaciol., 3, 103106.

Glen, J. W. 1955. The creep of polycrystalline ice. Proc. $R$. Soc. London, Ser. A, 228(1175), 519-538.

Grosswald, M. G. 1988. Antarctic-style ice sheet in the Northern Hemisphere: toward a new global glacial theory. Polar Geogr. Geol., 12(4), 239-267.

Holdsworth, G. 1969. Flexure of a floating ice tongue. $\mathcal{J}$. Glaciol., 8(54), 385-397.

Holdsworth, G. 1971. Calving from Ward-Hunt Ice Shelf, 1961-1962. Can. J. Earth Sci., 8(2), 299-305.

Holdsworth, G. 1973. Ice calving into the proglacial Generator Lake, Baffin Island, N.W.T., Canada. 7 . Glaciol., 12(65), 235-250.

Holdsworth, G. 1974. Erebus Glacier tongue, McMurdo Sound, Antarctica. 7. Glaciol., 13(67), 27-35.

Holdsworth, G. 1977. Tidal interaction with ice shelves. Ann. Géophys., 33(1/2), 133-146.

Holdsworth, G. 1985. Some effects of ocean currents and wave motion on the dynamics of floating glacier tongues. In Jacobs, S.S., ed. Oceanology of the Antarctic continental shelf. Washington, DC, American Geophysical Union, 253-271. (Antarct. Res. Ser. 43.)

Holdsworth, G. and J. E. Glynn. 1978. Iceberg calving from floating glaciers by a vibration mechanism. Nature, 274(5670), $464-466$.

Holdsworth, G. and J. E. Glynn. 1981. A mechanism for the formation of large icebergs. 7 . Geophys. Res., 86(C4), 3210-3222.

Hughes, T. 1977. West Antarctic ice streams. Rev. Geophys. Space Phys., 15(1), 1-46.

Hughes, T. 1983. On the disintegration of ice shelves: the role of fracture. 7. Glaciol., 29(101), 98-117.

Hughes, T. 1986. The Jakobshavns effect. Geophys. Res. Lett., 13(1), 46-48.

Hughes, T. 1987. Deluge II and the continent of doom: rising sea level and collapsing Antarctic ice. Boreas, 16(2), 89-100.

Hughes, T. 1989. Calving ice walls. Ann. Glaciol., 12, 74 80.

Hughes, T. and M. Nakagawa. 1989. Bending shear: the rate-controlling mechanism for calving ice walls. $\mathcal{J}$. Glaciol., 35(120), 260-266.

Hughes, T., C. Parkinson and H. Brecher. 1976. Ice dynamics study of a glacial surge induced by the August 1970 eruption on Deception Island, Antarctica. In Gonzales Ferran, O., ed. Proceedings of the Symposium on "Andean and Antarctic Volcanology Problems" (Santiago, Chile, September 1974). Rome, International Association of Volcanology and Chemistry of the Earth's Interior, 112-133.

Iken, A. 1977. Movement of a large ice mass before breaking off. f. Glaciol., 19(81), 595-605.

Lingle, C. S., T. Hughes and R. C. Kollmeyer. 1981. Tidal flexure of Jakobshavns glacier, West Greenland. 7. Geophys. Res., 86(B5), 3960-3968.

Mayewski, P.A., G.H. Denton and T.J. Hughes. 1981. Late Wisconsin ice sheets of North America. In Denton, G. H. and T.J. Hughes, eds. The last great ice sheets. New York, etc., Wiley-Interscience, 67-178.

Meier, M.F. and 7 others. 1980. Predicted timing and disintegration of the lower reach of Columbia Glacier, Alaska. U.S. Geol. Surv. Open-File Rep. 78-264.

Paterson, W.S.B. 1981. The physics of glaciers. Second edition. Oxford, etc., Pergamon Press.

Paterson, W. S. B. and C. U. Hammer. 1987. Ice core and other glaciological data. In Ruddiman, W. F. and H. E. Wright, Jr, eds. North America and adjacent oceans during the last deglaciation. Boulder, CO, Geological Society of America, 91-109.

Pelto, M. S., T.J. Hughes and H.H. Brecher. 1989. Equilibrium state of Jakobshavns Isbræ, West Greenland. Ann. Glaciol., 12, 127-131.

Popov, E. P. 1952. Mechanics of materials. Englewood Cliffs, NJ, Prentice-Hall.

Reeh, N. 1968. On the calving of ice from floating glaciers and ice shelves. F. Glaciol., 7(50), 215-232.

Robin, G.de Q. 1958. Glaciology III. Seismic shooting and related investigations. Norwegian-British-Swedish Antarctic Expedition, 1949-1952. Sci. Results, 5.

Robin, G. de Q. 1979. Formation, flow, and disintegration of ice shelves. F. Glaciol., 24(90), 259-271.

Sikonia, W. G. 1982. Finite-element glacier dynamics model applied to Columbia Glacier, Alaska. U.S. Geol. Surv. Prof. Pap. 1258-B.

Stuiver, M., G.H. Denton, T.J. Hughes and J.L. Fastook. 1981. History of the marine ice sheet in West Antarctica during the last glaciations: a working hypothesis. In Denton, G. H. and T.J. Hughes, eds. The last great ice sheets. New York, etc., Wiley-Interscience, 319-436.

Teller, J. T. 1987. Proglacial lakes and the southern margin of the Laurentide ice sheet. In Ruddiman, W.F. and H.E. Wright, Jr, eds. North America and adjacent oceans during the last deglaciation. Boulder, CO, 
Geological Society of America, 39-69.

Thomas, R.H. and C.R. Bentley. 1978. A model for Holocene retreat of the West Antarctic ice sheet. Quat. Res., 10(2), 150-170.

Vinogradov, O. G. and G. Holdsworth. 1985. Oscillation of a floating glacier tongue. Cold Reg. Sci. Technol., 10(3), 263-271.

The accuracy of references in the text and in this list is the responsbility of the author, to whom queries should be addressed.

MS received 30 May 1991 and in revised form 9 September 1991 